\title{
RADIO I TV VESTI U NASTAVI VEŠTINE RAZUMEVANJA GOVORA STRANOG JEZIKA STRUKE - PRIMENA STRATEGIJA
}

Napredak tehnologije u proteklih nekoliko decenija doveo je do značajnog porasta broja televizijskih, radio kanala i informativnih portala na internetu. S obzirom na to da proizvode ogroman broj sati programa vesti u realnom vremenu, ovi mediji pružaju mnoštvo autentičnog audio i video materijala koji predstavlja bogat resurs u nastavi stranih jezika.

Pedagoška vrednost ove vrste materijala za razvijanje veštine razumevanja govora ispitana je na 83 studenta ekonomije koji engleski jezik uče kao jezik struke. Sprovedeno istraživanje imalo je za cilj da utvrdi da li izloženost radio i TV vestima posle dva semestra nastave dovodi do poboljšanja veštine razumevanja govora, i u kom formatu je ono izraženije: audio ili video. Drugi cilj istraživanja bio je da ispita da li sistematska nastava strategija razumevanja govora dovodi do poboljšanja u razumevanju ove dve vrste inputa. Poređenjem rezultata predtesta i posttesta po završenoj nastavi utvrđeno je da su ispitanici eksperimentalne grupe, koji su bili izloženi sistematskoj nastavi strategija razumevanja govora, više napredovali u razumevanju govora u odnosu na ispitanike kontrolne grupe, kao i da je veći napredak u obe grupe zabeležen kod razumevanja TV vesti. Ovi rezultati u korist video formata i strategija razumevanja govora potvrđuju značaj njihove primene u nastavi.

Ključne reči: radio i TV vesti, veština slušanja i razumevanja govora, strategije razumevanja govora, neverbalna komunikacija.

\section{Uvod}

Tehnološki razvoj u proteklih nekoliko decenija doveo je do znatnog porasta broja radio i televizijskih kanala i informativnih portala na internetu. Veliki broj autentičnih tekstova, prvenstveno vesti,

1 ksenijamaltez@yahoo.com 
predstavljenih u audio ili video formatu, koje ovi mediji svakodnevno emituju, predstvalja dragocen resurs za nastavu stranih jezika.

Kada je reč o nastavi veštine razumevanja govora, prednost primene ove vrste inputa ne zasniva se samo na činjenici da pruža obilje prilika za nerecipročno slušanje i razumevanje, već i važan, alternativni izvor informacija. Dugogodišnja praksa nam potvrđuje da primena televizijskih i radio vesti u nastavi značajno pospešuje motivaciju studenata, pružajući im obilje informacija o aktuelnim događajima, temama povezanim s njihovim predmetom studiranja, kao i kulturi jezika koji uče. Vrednost primene ove vrste inputa u nastavi leži upravo $\mathrm{u}$ preklapanju pedagoškog i informativnog aspekta.

Budući da je jedan od ciljeva nastave osposobljavanje učenika da koriste izvore jezičkih informacija koji su raspoloživi i van učionice, primena ovih resursa u velikoj meri doprinosi ostvarenju tog cilja.

U tom smislu, jedan od ciljeva ovog istraživanja jeste da utvrdi da li primena radio i TV vesti u nastavi tokom dva jezička kursa dovodi do poboljšanja veštine razumevanja govora, i u kom formatu je ono izraženije (audio ili video).

Autentičan diskurs radio i TV vesti karakterišu brzina govora na koju učenici možda nisu navikli, specifična struktura diskursa, formalni registar, velika gustina informacija i izgovor govornika iz različitih delova sveta, pa se može pretpostaviti da će učenici imati teškoća u tumačenju ove vrste inputa. Jedan broj istraživača polazi od pretpostavke da orijentisanje učenika na strategije razumevanja govora može da im pomogne u prevazilaženju pomenutih teškoća u razumevanju (Mendelson 1994; Šamo 2005; Vandergrift 1999).

Polazeći od ove tvrdnje, drugi cilj istrživanja bio je da utvrdi da li sistematska nastava strategija razumevanja govora dovodi do boljih rezultata studenata u razumevanju TV i radio vesti, odnosno doprinosi poboljšanju veštine razumevanja govora.

\section{Pregled ranijih istraživanja}

Video mediji se već neko vreme koriste u nastavi stranih jezika. Glavna pretpostavka u osnovi ove prakse jeste ta da prisustvo 
neverbalnih, vizuelnih komponenti značenja teksta može da olakša razumevanje audio komponente inputa. Pod „video medijima“ podrazumeva se „skup medija kod kojih se spajanjem dinamičnih vizuelnih elementa sa audio elementima stvara celokupna poruka" (Gruba 1997: 335).

Neverbalno ili kinezičko ponašanje predstavlja deo „ljudske komunikativne interakcije" koja obuhvata pokrete i držanje tela, gestove, izraze lica ili pokrete glavom (Kelerman 1992). Ono prati govor bilo da su učesnici u komunikaciji toga svesni ili ne. Kako se značenje ovih vanjezičkih elemenata poruke koji dolaze video kanalom u velikoj meri poklapa sa značenjem koje dolazi putem audio kanala, „kinezičko ponašanje [u suštini] predstavlja još jedan vid jezičke redundanse" (Rafler-Eindžel 1980 u Vagner 2010: 494).

Veliki broj istraživača smatra da upotreba video inputa u nastavi dovodi do poboljšanja razumevanja govora na stranom jeziku zahvaljujući tome što omogućuje učenicima da prate kinezičko ponašanje govornika. Zato su pedagoška vrednost ove vrste inputa i mogućnost upotrebe TV vesti, kao žanra, na različitim nivoima učenja stranog jezika u cilju unapređenja jezičkih veština bili predmet brojnih istraživanja.

Ipak, njihovi rezultati po ovom pitanju nisu jedinstveni. Dok su neka istraživanja potvrdila da upotreba video inputa dovodi do boljih rezulata razumevanja govora (Ginter 2002; Sueioši i Hardison 2005; Vagner 2010), ima istraživanja koja iznose suprotne dokaze (Gruba 1999; Bret 1997).

Gruba (Gruba 1999: 277), na primer, tvrdi da „vizuelni elementi nude mogućnosti za razvoj razumevanja paralelno sa verbalnim elementima", ali istovremeno primećuje da oni često za njegove studente predstavljaju vid distrakcije, pa ih oni zanemaruju u tumačenju poruke. Bret (Bret 1997) primećuje da su ispitanici u njegovom istraživanju pokrivali oči rukama u toku aktivnosti slušanja kako bi se usredsredili isključivo na govor, što očito potvrđuje da je za ove učenike prisustvo video komponente remetilo koncentraciju.

Imajući u vidu da su rezultati do sada sprovedenih istaživanja na ovu temu donekle suprotstavljeni, potrebno je sprovesti nova istraživanja koja će ispitati kako upotreba video inputa može da utiče na veštinu razumevanja govora na stranom jeziku. 
Što se tiče strategija učenja jezika, interesovanje za njih postoji preko 30 godina. Rezultati istraživanja strategija su značajni za učenje i nastavu stranih jezika iz dva razloga: istraživanjem strategija koje učnici koriste u toku procesa učenja jezika stiče se uvid u kognitivne, metakognitivne, društvene i afektivne procese obuhvaćene učenjem jezika. Osim toga, istraživači veruju da se proučavanjem strategija koje koriste uspešniji učenici, kao i razlika u upotrebi strategija između uspešnijih i manje uspešnih učenika, može pronaći optimalni način podučavanja strategija u nastavi (Šamo 2005).

Većina istraživanja strategija učenja jezika je deskriptivne prirode, dok postoji znatno manje eksperimentalnih istraživanja posvećenih nastavi strategija u učionici. Njihovi rezultati, međutim, pokazuju da nastava strategija razumevanja govora ima pozitivan uticaj na veštinu razumevanja govora (Tompson i Rubin 1996; Ozeki 2000; Kerier 2003; Vandergrift 2003).

Iz tog razloga i novija literatura o nastavi veštine razumevanja govora na stranom jeziku podržava ideju da nastava strategija razumevanja govora, bilo eksplicitna, ili implicitna vodi poboljšanju ove veštine ${ }^{2}$.

\section{Metodologija}

Predmet ovog longitudinalnog empirijskog istraživanja jeste ispitivanje efikasnosti nastave strategija razumevanja govora za razumevanje sadržaja televizijskih i radio vesti. Osnovna varijabla u istraživanju je veština razumevanja govora, dok je napredak ispitanika posmatran kroz postignuće na posttestu, zasnovanom na audio i video inputu.

Istraživanje nastoji da odgovori na pitanja:

2 Eksplicitnu nastavu strategija razumevanja govora zagovaraju teoretičari Rebeka Oksford (Oxford, R. L. (1990). Language learning strategies: What every teacher should know. New York: Newbury House); Omali i Šamo (O'Malley, J. M., Chammot, A. U. (1990). Learning Strategies in Second Language Acquisition. Cambridge: CUP) i Dejvid Mendelson (Mendelson 1994), dok prednost implicitnoj nastavi strategija nad direktnom, eksplicitnom, daju autori Džon Fild (Fild 2008), Kristin Gou (Gou 2008) i Leri Vandergrift (Vandergrift 2003). 
RADIO I TV VESTI U NASTAVI VEŠTINE RAZUMEVANJA GOVORA...

1. Da li učenici koji su izloženi nastavi strategija razumevanja govora (eksperimentalna grupa) imaju bolje rezultate u razumevanju TV i radio vesti u odnosu na učenike koji nisu izloženi nastavi strategija (kontrolna grupa)?

2. Pri kom formatu (video ili audio) ispitanici postižu bolje rezultate u razumevanju govora po sprovedenoj nastavi strategija?

\subsection{Opis uzorka i instrumenti}

Istraživanje je sprovedeno na grupi od 83 studenta ekonomije koji uče engleski kao jezik struke i trajalo je 120 časova ili dva akademska kursa na B1-B2 nivou učenja prema Zajedničkom evropskom referentnom okviru za jezike. Ispitanici su podeljeni metodom slučajnog izbora u dve grupe, eksperimentalnu i kontrolnu.

Za ispitivanje efikasnosti modela nastave strategija razumevanja govora primenjenog u istrživanju upotrebljeni su sledeći instrumenti: ulazni test za određivanje nivoa razvijenosti veštine razumevanja govora ispitanika pre istraživanja (u ove svrhe upotrebljen je deo standardnog IELTS testa koji se odnosi na testiranje razumevanja govora), predtest i posttest veštine razumevanja govora. Oba ova testa bila su sastavljena iz pitanja višečlanog izbora koja proveravaju razumevanje TV i radio vesti, a svaki od testova imao je po tri seta televizijskih i isto toliko radijskih vesti sa govornicima sa britanskog ili američkog govornog područja. Teme obrađene u vestima odnosile su se na ekonomska, politička ili pitanja u vezi sa kulturom.

\subsection{Procedura}

Ispitanici obe grupe koristili su isti udžbenik i bili izloženi istom, posebno izabranom i pripremljenom video i audio inputu u okviru nastave razumevanja govora. Izabrane radio i televizijske vesti, kao primeri autentičnog jezika, pružile su brojne prilike za smisleno slušanje i razumevanje govora na stranom jeziku nerecipročnog tipa, i istovremeno poslužile kao direktni izvor informacija o aktuelnim događajima, predmetu studija ili interesovanja ispitanika, što je imalo za cilj da poveća njihovu motivaciju za slušanje. 
Aspekti kojima smo posvetili pažnju pri izboru vesti, ali i u samoj nastavi i testiranju veštine razumevanja govora odnose se na:

a) sadržaj, odnosno prethodno stečeno znanje o određenoj temi, poznavanje konteksta i kulturnih normi;

b) karakteristična svojstva strukture diskursa i žanra vesti;

c) jezičku težinu teksta (leksičko-sintaksička priroda teksta: nepoznati vokabular ili sintaksičke strukture; akustičke prepreke poput brzine govora, pauza, oklevanja, varijacija u izgovoru; kinezički signali i pokapanje/nepoklapanje između informacija sadržanih u tekstu koje dolaze audio kanalom, s jedne, i vizuelnim putem s druge strane u slučaju TV vesti).

Aspekti televizijskih vesti ključni za razumevanje koji su posebno obrađeni u nastavi odnose se na kinezičko ponašanje kao deo ljudske komunikativne interakcije (pokreti tela, gestovi, izrazi lice, držanje) i prisustvo teksta u slici (naslovi, natpisi, reči i simboli) i njegovo tumačenje.

U radu sa obema grupama primenjen je procesni pristup (eng. process approach, (Fild 2008)), koji podrazumeva ovladavanje procesima koji su u osnovi veštine razumevanja govora: uzlaznim (dekodiranje poruke povezivanjem jezičkih jedinica od najmanjih - fonema, preko reči, fraza, do onih na nivou diskursa) i silaznim (građenje značenja oslanjanjem na prethodno znanje o temi, žanru, kontekstu, kulturi). Kod izvornih govornika ovi procesi su automatizovani, dok kod učenika, naročito na nižim nivoima učenja jezika, to nije slučaj zbog ograničenog jezičkog znanja kojim raspolažu, te ih je bilo potrebno sistematski razvijati u nastavi.

S druge strane, važnu ulogu u prevazilaženju trenutnog jezičkog znanja učenika i zahteva situacije realne upotrebe jezika igraju uprvo strategije razumevanja govora. Da bismo proverili u kojoj meri njihova primena doprinosi unapređenju veštine razumevanja govora naših studenata, obuhvatili smo ih nastavom ispitanika eksperimentalne grupe, dok je kod kontrolne grupe nastava strategija razumevanja govora izostala. To je ključni aspekt po kome se nastava eksperimentalne razlikovala od nastave kontrolne grupe.

U radu sa eksperimentalnom grupom primenjen je eklektički model nastave strategija, čija se prednost prvenstveno ogleda u tre- 
tiranju različitih tipova strategija, pa su tako proaktivne ili metakognitivne strategije podučavane putem direktne nastave, dok su reaktivne ili kognitivne strategije podučavane implicitnim putem ${ }^{3}$.

Direktna nastava podrazumevala je razvijanje svesti učenika o strategijama i strateškog mišljenja, identifikovanje strategija po imenu, demonstriranje njihove primene, pružanje brojnih prilika za uvežbavanje, kasniju evaluaciju upotrebljenih strategija i transfer na nove zadatke.

Indirektna nastava strategija ${ }^{4}$ bila je usmerena na usvajanje proceduralnog znanja upotrebe strategija (kako), a ne deklarativnog znanja (šta), pri čemu je cilj aktivnosti bila postepena automatizacija kognitivnih i metakognitivnih procesa razumevanja govora. Uvežbavanje primene strategija implicitnim putem obuhvatilo je brojne prilike za slušanje TV i radio vesti, postavljanje pretpostavki u vezi sa značenjem, predviđanje, oslanjanje na selektivnu pažnju, praćenje tačnosti sopstvenog razumevanja i proveru prethodno postavljenih pretpostavki, i konačno evaluaciju sopstvenog učinka. Ponavljanje ovog metakognitivnog ciklusa ${ }^{5}$ u obavljanju zadataka, samostalno ili uz pomoć drugih učenika, i tumačenje značenja novih informacija koje neprestano dolaze u realnom vremenu imali su za cilj razvoj veštine razumevanja govora implicitnim putem, odnosno približavanje procesa koje učenici primenjuju u razumevanju govora rutinskim procesima obrade poruke karakterističnim za izvorne govornike.

Polazeći od jezičkih veština i sposobnosti neophodnih za razumevanje govora audio i video medija opisanih u Zajedničkom evropskom referentnom okviru jezika $\left(\mathrm{CEFR}^{6}\right)$ na B1-B2 nivou, izdvojili smo listu veština koje smo testirali na predtestu i posttestu razumevanja govo-

3 Kognitivne ili reaktivne strategije koriste se kada slušalac teba da prevaziđe nepredviđeni problem u razumevanju, $\mathrm{u}$ trenutku kada njegova sposobnost dekodiranja i jezičko znanje nisu dovoljni da protumači poruku. Metakognitivne ili proaktivne strategije ne predstavljaju kompenzaciju za nedostatak jezičkog znanja slušaoca, već pomažu zadržavanje informacija; one podrazumevaju element planiranja i praćenja razumevanja.

$4 \quad$ Omali i Šamo je još nazivaju i integrisanom nastavom strategija (eng. embedded instruction).

5 Primenu ovog ciklusa opisao je Vandergrift u svom istraživanju (2003).

6 CEFR - https://www.coe.int/t/dg4/linguistic/Source/Framework_EN.pdf 
ra: a) sposobnost razumevanja glavnih ideja pregleda TV ili radio vesti, b) prepoznavanje specifičnih detalja i činjenica u tekstu snimljenog ili uživo prezentovanog materijala izgovorenog standardnim izgovorom, c) sposobnost razumevanja organizacije teksta, tj. određivanja odnosa između osnovnih i sporednih ideja u okviru diskursa, d) izvođenje zaključaka na osnovu teksta (zaključivanje na osnovu propozicija iznetih u tekstu; zaključivanje na osnovu uzročno posledičnih odnosa u tekstu; pragmatičko zaključivanje, tj. ono koje se oslanja na vanliteralnu inpterpretaciju teksta i predznanje o temi) i e) sposobnost razumevanja stavova, mišljenja, raspoloženja ili tona govornika.

Po isteku dva jezička kursa rezultati predtestiranja i posttestiranja statistički su obrađeni i analizirani uz pomoć kvantitativne i kvalitativne analize.

\section{Rezultati istraživanja i diskusija}

Uticaj nastave strategija razumevanja govora na postignuće ispitanika eksperimentalne i kontrolne grupe na posttestu veštine razumevanja govora ispitan je prostom linearnom regresijom i višestrukom linearnom regresijom. Sva testiranja vršena su u programskom paketu MATLAB, verzija 2014a.

\subsection{Statistička analiza za zavisno promenljivu TV vesti}

1. Primenom proste linearne regresije ispitana je zavisnost rezultata dobijenih na posttestu od rezultata predtesta razumevanja TV vesti. Rezultati su međusobno upoređeni za kontrolnu i eksperimentalnu grupu. Prosta linearna regresija pokazala je sledeće zavisnosti:

- $\quad$ za kontrolnu grupu: posttest TV vesti $=0.37084+0.96958 *$ predtest TV vesti;

$\mathrm{R}^{2}=0.805(80,5 \%$ promena na posttestu TV vesti je objašnjeno ovom zavisnošću); dobijene p vrednosti su veoma zadovoljavajuće.

- $\quad$ za eksperimentalnu grupu: posttest TV vesti $=0.8566+$ 0.96689* predtest TV vesti; 
$\mathrm{R}^{2}=0.895(89.5 \%$ promena na posttestu TV vesti je objašnjeno ovom zavisnošću); dobijene p vrednosti su veoma zadovoljavajuće.

Slika 1 pokazuje da su i crvena i plava linija regresije iznad crne isprekidane linije koja označava nivo „bez promene“. To znači da su i kontrolna i eksperimentalna grupa ostvarile napredak na posttestu u odnosu na predtest, odnosno da je kod obe grupe došlo do poboljšanja rezultata prve posmatrane zavisno promenljive razumevanje TV vesti. Međutim, na osnovu slike primećujemo da je taj napredak izraženiji kod eksperimentalne grupe u odnosu na kontrolnu (crvena linija je iznad plave linije) u čitavom opsegu posmatranja.

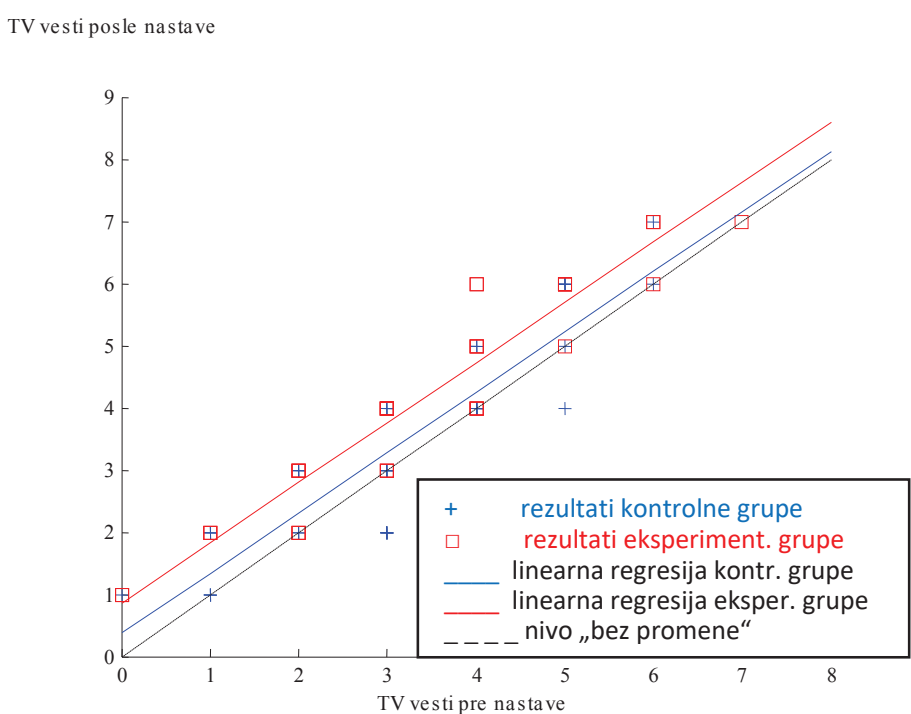

Sl. 1 Prosta linearna regresija za TV vesti

2. Primenom proste linearne regresije na proveravanje zavisnosti predtesta TV vesti od ulaznog testa dobijene su sledeće zavisnosti:

- za kontrolnu grupu: predtest TV vesti $=-2.7653+0.39901 * u l a-$ zni test;

$\mathrm{R}^{2}=0.848(84,8 \%$ promena predtesta TV vesti je objašnjeno ovom zavisnošću); dobijene p vrednosti su veoma zadovoljavajuće. 
- za eksperimentalnu grupu: predtest $\mathrm{TV}$ vesti $=-2.7653+$ 0.39901* ulazni test;

$\mathrm{R}^{2}=0.851(85,1 \%$ promena predtesta $\mathrm{TV}$ vesti je objašnjeno ovom zavisnošću); dobijene p vrednosti su veoma zadovoljavajuće.

Primena proste linearne regresije na utvrđivanje zavisnosti predtesta TV vesti od ulaznog testa bila je neophodna da bismo potom pravilno analizirali rezultate višestruke linearne regresije, odnosno precizno odredili oblast defenisanosti zavisno promenljive od posmatranih nezavisnih promenljivih.

Slika 2 pokazuje da su rezultati za promenljivu predtest TV vesti izrazito pozitivno linearno zavisni od rezultata za promenljivu ulazni test, odnosno da ispitanici sa visokim vrednostima rezultata na ulaznom testu imaju i visoke vrednosti rezultata na predtestu veštine razumevanja TV vesti, i obrnuto. Oblast od interesa za analizu višestruke linearne regresije zavisno promenljive posttest TV vesti od promenljivih predtest TV vesti i ulazni test grubo je određena sa: male vrednosti predtesta TV vesti i male vrednosti ulaznog testa, srednje vrednosti predtesta TV vesti i srednje vrednosti ulaznog testa, velike vrednosti predtesta TV vesti i velike vrednosti ulaznog testa.

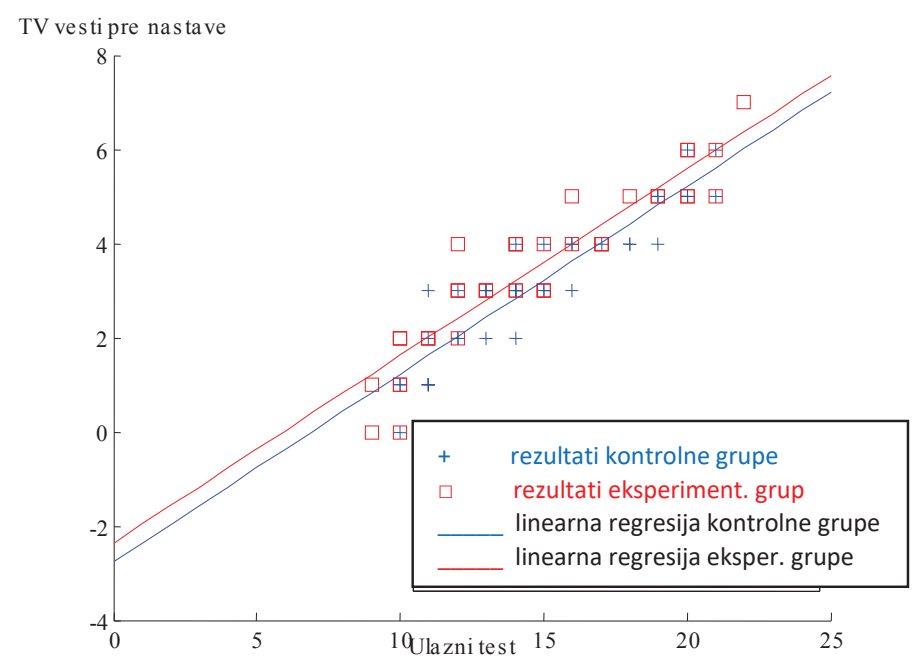

Sl. 2 Prosta linearna regresija za zavisnost TV vesti pre nastave od ulaznog testa 
RADIO I TV VESTI U NASTAVI VEŠTINE RAZUMEVANJA GOVORA...

3. Višestrukom linearnom regresijom ispitana je zavisnost rezultata posttesta TV vesti od rezultata predtesta TV vesti i rezultata ulaznog testa, i dobijene su sledeće zavisnosti:

- $\quad$ za kontrolnu grupu: posttest TV vesti $=-2.1113+0.32111^{*}$ predtest TV vesti

$+0.30521^{*}$ ulazni test; $R^{2}=0.869(86,9 \%$ promena posttesta TV vesti je objašnjeno ovom zavisnošću); dobijene p vrednosti su veoma zadovoljavajuće;

- $\quad$ za eksperimentalnu grupu: posttest TV vesti $=-0.13443+$ $0.67149 *$ predtest TV vesti +

0.13763* ulazni test; $\mathrm{R}^{2}=0.91$ ( $91 \%$ promena posttesta TV vesti je objašnjeno ovom zavisnošću); dobijene p vrednosti su veoma zadovoljavajuće.

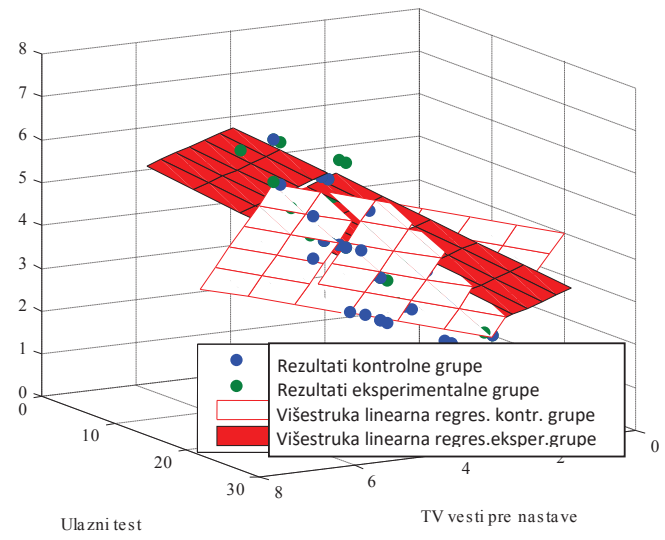

Sl.3 Višestruka linearna regresija za TV vesti

Rezultati višestruke linearne regresije potvrdili su da je eksperimentalna grupa više napredovala u odnosu na kontrolnu na posttestu razumevanja TV vesti u oblasti od interesa (male vrednosti predtesta TV vesti i male vrednosti ulaznog testa, srednje vrednosti predtesta TV vesti i srednje vrednosti ulaznog testa, velike vrednosti predtesta TV vesti i velike vrednosti ulaznog testa), što je uočljivo i na slici 3: crvena obojena površina je iznad crvene rešetkaste površine. 
Dakle, rezulati za prvu posmatranu zavisno promenljivu u istraživanju, razumevanje TV vesti, dobijeni primenom metoda proste i višestruke linearne regresije pokazali su da su obe grupe ostvarile napredak na posttestu razumevanja TV vesti u odnosu na nivo „bez promene", ali da je eksperimentalna grupa više napredovala u odnosu na kontrolnu u čitavom opsegu posmatranja.

Smatramo da je postignuti napredak na posttestu razumevanja TV vesti kod obe grupe ispitanika rezultat dva faktora. Prvi se odnosi na veći stepen automatizacije procesa u osnovi razumevanja govora do koga je došlo pod uticajem primene procesnog pristupa razumevanju govora u nastavi, a drugi na izloženost autentičnom video inputu, odnosno vizuelnoj komponenti značenja čije su karakteristike ispitanici obe grupe naučili da tumače u toku dva jezička kursa.

Rezultati koji govore u prilog primene video inputa u nastavi, kao faktora koji pozitivno utiče na razumevanje govora, potvrđeni su i u ranijim istraživanjima (Gruba 1999, Sueioši i Hardison 2005; Vagner 2010; Vutipong 2014).

Međutim, kako je napredak na posttestu izraženiji kod eksperimentalne grupe u čitavom opsegu posmatranja, značajnu razliku u postignuću u korist njenih ispitanika možemo pripisati primeni strategija u nastavi razumevanja govora ove grupe, budući da je to bila jedina razlika u tretmanu između dve grupe ispitanika. Pozitivan uticaj nastave strategija na razumevanje govora potvrđen je i rezultatima ranijih istraživanja (Tompson i Rubin 1996; Ozeki 2000; Vandergrift i Tafaghodtari, 2010).

\subsection{Statistička analiza za zavisno promenljivu radio vesti}

Primenom proste linearne regresije ispitana je zavisnost rezultata dobijenih na posttestu od rezultata predtesta razumevanja radio vesti za kontrolnu i eksperimentalnu grupu. Prosta linearna regresija pokazala je sledeće zavisnosti:

- $\quad$ za kontrolnu grupu: posttest radio vest $\mathrm{i}=-0.16302+1.1365^{*}$ predtest radio vesti;

$\mathrm{R}^{2}=0.838(83,8 \%$ promena posttesta radio vesti je objašnjeno ovom zavisnošću); dobijene p vrednosti su veoma za- 
dovoljavajuće, osim za konstantan član u ovoj analizi kontrolne grupe. Ta velika p-vrednost ukazuje na mogućnost da je taj član jednak nuli, što ne utiče na dobijene zaključke.

- $\quad$ za eksperimentalnu grupu: posttest radio vesti $=1.188+$ $0.85225^{*}$ predtest radio vesti;

$\mathrm{R}^{2}=0.855(85.5 \%$ promena posttesta radio vesti je objašnjeno ovom zavisnošću); dobijene p vrednosti su veoma zadovoljavajuće.

Na osnovu slike 4 (vidi dalje u tekstu) zaključujemo da su i eksperimentalna i kontrolna grupa ostvarile napredak u razumevanju radio vesti (i crvena i plava linija su iznad crne isprekidane linije, koja označava nivo bez promena), ali da su grupe različito napredovale $u$ različitom opsegu posmatranja. Tako je eksperimentalna grupa više napredovala od kontrolne za ispitanike sa nižim i srednjim vrednostima rezultata na predtestu radio vesti (crvena linija iznad plave linije za vrednosti rezultata do broja 5), dok je kontrolna grupa više napredovala od eksperimentalne posmatrajući ispitanike sa višim vrednostima na predtestu radio vesti (plava linija iznad crvene linije za vrednosti rezultata preko 5). Kako grafikon pokazuje, ispitanici obe grupe sa 5 poena na predtestu napredovali su podjednako.

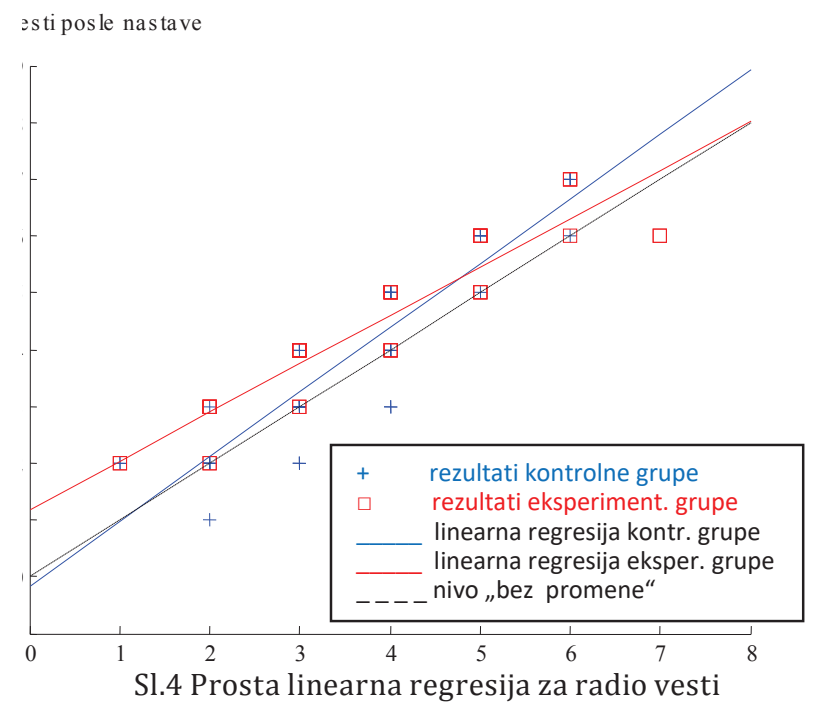


Međutim, analizom pojedinačnih rezultata ispitanika obe grupe za najviše vrednosti na predtestu (6 i 7 bodova) utvrdili smo da je samo eksperimentalna grupa imala dva ispitanika sa najvećim brojem bodova na predtestu, i oni na posttestu nisu napredovali $(7$ predtest - 6 posttest). Ovaj rezultat vidi se i na slici 4 . Kada je reč o ispitanicima sa po 6 bodova na predtestu, u obe grupe ih je bilo po četvoro; od toga je po troje napredovalo za po jedan bod (sa 6 na 7), dok je po jedan ispitanik stagnirao ( 6 bodova predtest -6 bodova posttest), tako da je napredak ispitanika koji su imali po 6 bodova na predtestu u obe grupe izjednačen. Ukoliko bismo rezultat dva ispitanika eksperimentalne grupe sa po 7 bodova koji su nazadovali na posttestu izostavili iz analize (oni čine 4,65\% uzorka ove grupe), mogli bismo da konstatujemo da ispitanici eksperimentalne grupe sa 6 bodova na predtestu ipak nisu manje napredovali od ispitanika kontrolne grupe, već da je njihov napredak gotovo izjednačen. Plava i crvena linija regresije bi u tom slučaju imale slično kretanje.

1. Primenom proste linearne regresije na zavisnost predtesta radio vesti od ulaznog testa dobijene su sledeće zavisnosti:

- zakontrolnu grupu: predtest radio vesti $=-1.7641+0.36014^{*}$ ulazni test; $\mathrm{R}^{2}=0.862$

(86,2\% promena na predtestu radio vesti je objašnjeno ovom zavisnošću); dobijene p vrednosti su veoma zadovoljavajuće.

- za eksperimentalnu grupu: predtest radio vesti = $-1.536+0.36765^{*}$ ulazni test; $\mathrm{R}^{2}=0.831$

$(83,1 \%$ promena na predtestu radio vesti je objašnjeno ovom zavisnošću); dobijene p vrednosti su veoma zadovoljavajuće.

Primena proste linearne regresije na utvrđivanje zavisnosti predtesta radio vesti od ulaznog testa je, kao i kod TV vesti, bila neophodna da bi se kasnije pravilno analizirali rezultati višestruke linearne regresije, odnosno precizno odredile oblasti defenisanosti zavisno promenljive od posmatranih nezavisnih promenljivih.

Slika 5 pokazuje da je promenljiva predtest radio vesti jako pozitivno linearno zavisna od promenljive ulazni test, što znači da su 
ispitanici sa visokim vrednostima rezultata na ulaznom testu imali i visoke vrednosti rezultata na predtestu veštine razumevanja radio vesti, i obrnuto. Oblast od interesa za analizu višestruke linearne regresije zavisno promenljive posttest radio vesti od promenljivih predtest radio vesti i ulazni test grubo je određena sa: male vrednosti predtesta radio vesti i male vrednosti ulaznog testa, srednje vrednosti predtesta radio vesti i srednje vrednosti ulaznog testa, velike vrednosti predtesta radio vesti i velike vrednosti ulaznog testa.

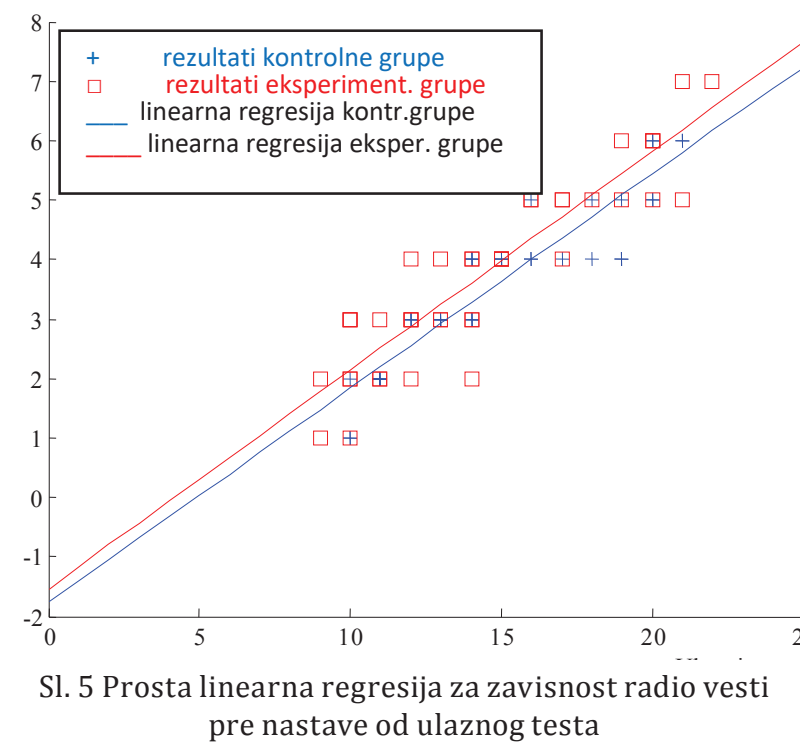

2. Višestrukom linearnom regresijom ispitana je zavisnost rezultata posttesta radio vesti od rezultata predtesta radio vesti i rezultata ulaznog testa, i dobijene su sledeće zavisnosti:

- $\quad$ za kontrolnu grupu: posttest radio vesti $=-2.1694+0.37019 *$ predtest radio vesti

$+0.32013^{*}$ ulazni test; $\mathrm{R}^{2}=0.899(89,9 \%$ promena posttesta radio vesti je objašnjeno ovom zavisnošću); dobijene $p$ vrednosti su veoma zadovoljavajuće.

- za eksperimentalnu grupu: posttest radio vesti $=0.82294+$ $0.71306^{*}$ predtest radio vesti 
$+0.061611^{*}$ ulazni test; $\mathrm{R}^{2}=0.86$ (86\% promena posttesta radio vesti je objašnjeno ovom zavisnošću); dobijene $p$ vrednosti su veoma zadovoljavajuće.

Radio vesti posle nastave

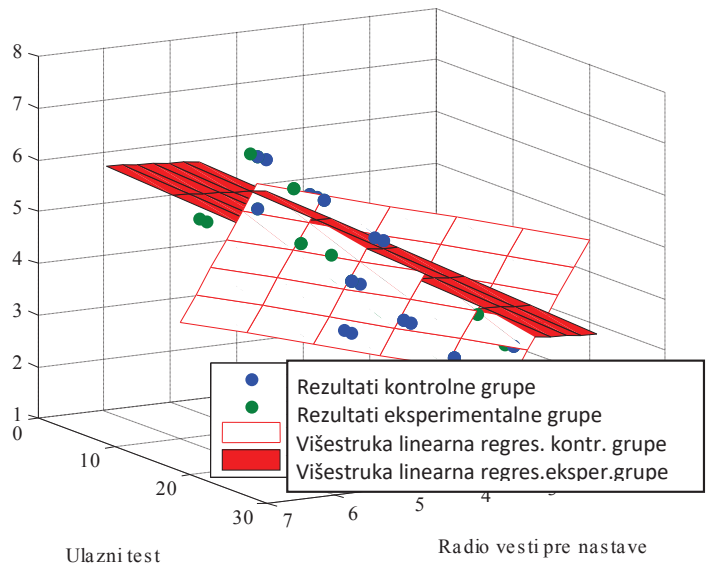

Sl. 6 Višestruka linearna regresija za radio vesti

Kako slika 6 pokazuje, u oblasti od interesa određenoj sa: male vrednosti predtesta radio vesti i male vrednosti ulaznog testa, srednje vrednosti predtesta radio vesti i srednje vrednosti ulaznog testa, eksperimentalna grupa je više napredovala od kontrolne grupe (crvena obojena površina je iznad crvene rešetkaste površine), dok je u oblasti: velike vrednosti predtesta radio vesti i velike vrednosti ulaznog testa eksperimentalna grupa manje napredovala od kontrolne grupe (crvena obojena površina je ispod crvene rešetkaste površine). Podrobnijom analizom pojedinačnih rezultata ispitanika obe grupe u opsegu posmatranja za velike vrednosti predtesta i velike vrednosti ulaznog testa utvrdili smo da su obe grupe gotovo podjednako napredovale.

Dakle, druga zavisno promenljiva koju smo posmatrali u istraživanju odnosi se na razumevanje radio vesti. Na osnovu rezultata proste i višestruke linearne regresije najveći napredak u okviru eksperimentalne grupe uočen je kod ispitanika sa nižim i srednjim 
vrednostima rezultata predtesta (zaključno sa 5 bodova), dok je kod ispitanika sa višim vrednostima rezultata (6 i 7) u obe grupe uočen podjednak napredak.

Smatramo da je do napretka kod obe grupe u razumevanju radio vesti, kao i kod TV vesti, došlo zahvaljujući primeni procesnog pristupa i ovladavanju procesima razumevanja govora u toku nastave, odnosno dostignutom većem stepenu automatizacije obrade informacija.

Međutim, uočljivu razliku u postignuću eksperimentalne grupe u odnosu na kontrolnu za ispitanike sa nižim i srednjim vrednostima rezultata predtesta možemo pripisati uticaju sistematske nastave strategija, budući da ona predstavlja jedinu razliku u tretmanu između dve grupe. I u ovom slučaju se dobijeni rezultati poklapaju sa rezultatima i zaključcima ranijih istraživanja koja su potvrdila prednost nastave strategija razumevanje govora na stranom jeziku upravo za učenike sa manje razvijenom veštinom razumevanja govora (Vandergrift 2003; Gou i Taib 2006; Gou 2008, Vandergrift i Tafaghodtari 2010).

Smatramo da su ispitanici eksperimentalne grupe u toku dva jezička kursa imali dovoljno vremena da razviju svest o kognitivnim i metakognitivnim strategijama i da primenom metakognitivnog ciklusa, postepeno ovladaju procesom razumevanja govora. U tom procesu stalna povratna reakcija nastavnika ili uspešnijih učenika u grupi bila je ključna za prilagođavanje strategija konkretnom problemu u razumevanju i uspešno tumačenje teksta.

Prema rezultatima istraživanja, ispitanici sa visokim vrednostima rezultata na predtestu u obe grupe ostvarili su sličan napredak. Imajući u vidu da kod obe grupe postoji pozitivna linearna korelacija između rezultata predtesta i ulaznog testa primenjenog pre istraživanja, moguće je da su procesi razumevanja govora kod ispitanika sa visokim vrednostima predtesta bili znatno razvijeniji i pre početka istraživanja, i u većoj meri automatizovani nego kod ispitanika sa nižim i srednjim vrednostima rezultata na predtestu. To dalje znači da se napredak ispitanika eksperimentalne grupe $u$ ovom opsegu posmatranja ne može pripisati isključivo sistematskoj primeni strategija u nastvi razumevanja govora. 


\section{Zaključak i pedagoške implikacije}

Na osnovu prethodno izloženih rezultata i njihove analize dolazimo do odgovora na prvo pitanje postavljeno u istraživanju, odnosno potvrđujemo da učenici koji su izloženi nastavi strategija razumevanja govora imaju bolje rezultate u razumevanju govora u odnosu na učenike u čijoj nastavi nema sistematske primene strategija.

Osim toga, poređenjem rezultata proste (slike 1 i 4) i višestruke linearne regresije (slike 3 i 6) za razumevanje TV vesti i radio vesti primećujemo da su ispitanci eksperimentalne grupe veći napredak ostvarili u razumevanju TV vesti. To znači da su ispitanici ove grupe u tumačenju teksta mogli da se oslone kako na strategije razumevanja govora tako i na vizuelnu komponentu značenja, i tako dođu do boljih rezultata na posttestu razumevanja TV vesti. Na posttestu razumevanja radio vesti korist od primene strategija razumevanja govora imali su prvenstveno ispitanici na nižem i srednjem nivou jezičkog znanja.

Kod ispitanika kontrolne grupe napredak u čitavom opsegu posmatranja vidljiv je kod razumevanja TV vesti, što nije slučaj kod razumevnja radio vesti. Kod ove druge vrste inputa ispitanici na nižem nivou jezičkog znanja nisu uopšte napredovali. To znači da je za ove ispitnike odsustvo vizuelne komponente značenja, odnosno izloženost samo audio inputu predstavljala otežavajući faktor u razumevanju.

$\mathrm{Na}$ osnovu ovih zaključaka dolazimo do odgovora i na drugo pitanje postavljeno u istraživanju, koje se odnosi na format inputa. Naime, sistematska nastava strategija razumevanja govora kojoj su ispitanici eksperimentalne grupe bili izloženi dovela je do napretka u razumevanju obe vrste inputa, ali se pokazalo da je taj napredak izraženiji kod TV vesti, odnosno video inputa.

Dobijeni rezultati ukazuju da bi zadatak nastavnika u vezi sa veštinom razumevanja govora trebalo da bude kreiranje niza aktivnosti koje bi obuhvatile sistematsku primenu strategija, kako kroz direktnu, tako i integrisanu nastavu. Istraživanje je pokazalo da su najviše koristi od primene strategija imali ispitanici na nižem i srednjem nivou učenja, što znači da bi sa nastavom strategija trebalo otpočeti na ranijim nivoima učenja jezika. Osposobljavanje učenika za razumevanje autentičnih tekstova i u ranijim fazama učenja jezika podstiče njihovo samopouzdanje u vezi sa razumevanjem govora, što može biti presudno za njihovu motivaciju i dalje učenje jezika. 
RADIO I TV VESTI U NASTAVI VEŠTINE RAZUMEVANJA GOVORA...

Rezultati istraživanja su takođe pokazali da su ispitanici u obe grupe više napredovali na testovima razumevanja televizijskih nego radio vesti, što potvrđuje da tumačenje vizuelnih elemenata poruke u interakciji sa verbalnom dimenzijom olakšava razumevanje poruke za učenike. Zato smatramo da nastava razumevanja govora mora neizostavno da obuhvati i ovladavanje elementima neverbalne komunikacije jer primena video inputa u nastavi priprema učenike za situacije upotrebe ciljnog jezika koje neizostavno mogu da očekuju i izvan učionice.

\section{Ograničenja istraživanja}

Istraživanje je potvrdilo da je sistematska nastava strategija razumevanja govora dovela do poboljšanja razumevanja radio i TV vesti na posttestiranju kod eksperimentalne grupe. Međutim, kako ispitanici po završenom posttestiranju nisu popunjavali upitnik o primenjenim strategijama u procesu razumevanja TV i radio vesti, nemamo informacija o konkretnim strategijama ili skupovima strategija na koje su se oni oslonili u razumevanju govora, pa ne možemo tvrditi da su se oslonili isključivo na strategije obuhvaćene nastavom. Takođe, bilo bi korisno znati kako su pojedinačni ispitanici na određenom nivou jezičkog znanja koristili strategije na posttestu razumevanja govora. Ova saznanja bi svakako bila korisna za dalje kreiranje nastave strategija razumevanja govora.

Osim toga, u ovom istraživanju obe vrste inputa, i audio i video, predstavljene su sa po 7 pitanja višečlanog izbora na predtestu, odnosno posttestu razumevanja TV i radio vesti. Ovim pitanjima provereno je prisustvo osnovnih podveština značajnih za razumevanje radio i TV vesti, navedenih u Zajedničkom evropskom referetnom okviru jezika. U daljim istraživanjima, međutim, bilo bi korisno proveriti prisustvo šireg raspona podveština razumevanja govora koje navode neki teoretičari ${ }^{7}$.

$7 \quad$ Primer jedne takve listu podveština koje je potrebno razvijati u okviru nastave razumevanja govora navodi Ričards u Richards, J.C. (1983). Listening comprehension: approach, design, procedure, TESOL Quarterly, 17(2), 219-240. 
Na kraju, smatramo da je potrebno sprovesti još istraživanja da bi dobijeni rezultati bili potvrđeni. Ona bi mogla da obuhvate veći uzorak ispitanika, ispitanike sa različitim nivoima jezičkog znanja, kao i više predavača u različitim nastavnim sredinama obučenim za primenu nastave strategija razumevanja govora.

\section{LITERATURA}

Bret 1997: Brett, P. A comparative study of the effects of the use of multimedia on listening comprehension. System, 25(1), 39-53.

Fild 2008: Field, J. Listening in the Language Classroom. Cambridge: CUP.

Ginter 2002: Ginther, A. Context and content visuals and performance on listening comprehension stimuli. Language Testing 19, 133-167.

Gou 2008: Goh, C. Metacognitive instruction for second language listening development: Theory, practice and research implications. RELC Journal 39(2), 188-213.

Gou i Taib 2006: Goh, C./ Taib, Y. Metacognitive instruction in listening for young learners. ELT Journal, 60, 222-232.

Gruba 1997: Gruba, P. The role of video media in listening assessment. System, 25(3), 335-345.

Gruba 1999: Gruba, P. The role of digital video media in second language listening comprehension. $\mathrm{PhD}$ Thesis, Department of Linguistics and Applied Linguistics, University of Melbourne [online], [http://hdl. handle.net/11343/38784, pristupljeno 10.1.2012].

Kelerman 1992: Kellerman, S. 'I See What You Mean': The Role of Kinesic Behaviour in Listening and Implications for Foreign and Second Language Learning. Applied Linguistics, 13, 239-258.

Kerier 2003: Carrier, K.A. Improving high school English language learners' second language listening through strategy instruction. Bilingual Research Journal, 27, 383-408.

Mendelson 1994: Mendelsohn, D. J. Learning to Listen: A Strategy-Based approach for the Second Language learner. Publisher: San Diego, CA: Dominie Press.

Ozeki 2000: Ozeki, N. Listening Strategy Instruction for Female EFL College Students in Japan. Tokyo: Macmillan Language House.

Rafler-Eindžel 1980: Raffler-Engel, W. Kinesics and paralinguistics: A neglected factor in second language research and teaching. Canadian Modern Language Review, 36, 225-237. 
Sueioši i Hardison 2005: Sueyoshi, A./ Hardison, D. M. The role of gestures and facial cues in second language listening comprehension. Language Learning 55(4), 661-699.

Šamo 2005: Chamot, A. Language learning strategy instruction: Current issues and research. Annual Review of Applied Linguistics, 25, 112-130.

Tompson i Rubin 1996: Thompson, I./ Rubin, J. Can strategy instruction improve listening comprehension? Foreign Language Annals, 29(3), 331-342.

Vandergrift 1999: Vandergirft, L. Facilitating second language listening comprehension: Acquiring successful strategies. ELTJournal 53(3), 168-176.

Vandergrift 2003: Vandergrift, L. Orchestrating strategy use: Toward a model of the skilled second language listener. Language Learning 53, 463-496.

Vandergrift i Tafaghodtari 2010: Vandergrift, L./ Tafaghodtari, M. Teaching L2 learners how to listen does make a difference: An empirical study. Language Learning, 60(2), 470-497.

Vagner 2010: Wagner, E. The effect of the use of video texts on ESL listening test-taker performance. Language Testing, 27(4), 493-513.

Vutipong 2014: Woottipong, K. Effect of Using Video Materials in the teaching of Listening Skills for University Students. International Journal of linguistics, 6(4), 200-212.

\title{
Ksenija Maltez
}

\section{DEVELOPING ESP LISTENING COMPREHENSION IN THE CONTEXT OF RADIO AND TV NEWS - THE USE OF STRATEGIES}

\begin{abstract}
Summary
Rapid development of technology over the past several decades has led to a significant increase in the number of television and radio channels, and news portals on the Internet. Given that they produce a large number of hours of real-time news programs, these media provide abundant audio and video resources in FL teaching.

The pedagogical value of this kind of authentic input for developing listening comprehension was examined on 83 students of economics
\end{abstract}


studying ESP at B1-B2 level. The aim of the research was to determine whether the exposure to radio and TV news results in the improvement in listening comprehension after two semesters of instruction, and in what format the potential improvement is more pronounced: audio or video. Another aim of the research was to examine whether systematic listening comprehension strategies instruction led to an improvement in the comprehension of these two types of input. Based on the pre-test post-test design, it was found that the experimental group respondents, who had been exposed to the systematic listening comprehension strategies instruction, outperformed control group, as well as achieved higher scores in TV news than radio news listening tasks. The results in favor of video format and the use of listening comprehension strategies confirm the importance of their implementation in the classroom.

Key words: Radio and TV news, listening comprehension, listening comprehension strategies, nonverbal communication. 